\title{
APLICATION OF REGRESSION ANALYSIS IN FEASIBILITY STUDIES OF CONSUMER CONNECTION TO DISTRICT HEATING SYSTEMS
}

\author{
Corina Chelmenciuc ${ }^{1 *}$, ORCID ID: 0000-0002-5126-8539, \\ Constantin Borosan ${ }^{1}$, ORCID ID: 0000-0003-1975-4577, \\ Vadim Lisnic², ORCID ID: 0000-0001-9871-9643

\begin{abstract}
${ }^{1}$ Technical University of Moldova, Stefan cel Mare pr. 168, Chisinau, MD-2004 Republic of Moldova
2JSC „Termoelectrica”, Tudor Vladimirescu st. 6, Chisinau, MD-2024 Republic of Moldova

*Corresponding author: Corina Chelmenciuc, corina.chelmenciuc@tme.utm.md
\end{abstract}

Received: 09. 14. 2021

Accepted: 10. 28. 2021

\begin{abstract}
Nowadays, both globally and in Europe, and nationally, there is a tendency to promote district heating systems to the detriment of individual ones to heat dwellings in urban areas. The need to develop the DHSs is indisputable considering the topicality of global warming, the depletion of the primary energy resources and the energy efficiency trend. This article presents the method of applying regression analysis in feasibility studies for the projects of new heat consumers connection to the district heating system (hereinafter - DHS) or previously disconnected consumers reconnection via individual heating points (hereinafter - IHP) when the necessary investments are to be borne by the DHS operator, and the thermal energy is produced in cogeneration. At the same time, it is demonstrated that there is a direct and linear correlation between fuel consumption and electricity and heat produced in cogeneration at CHP plant.
\end{abstract}

Keywords: cogeneration, domestic hot water, equation of a straight line, heating season, individual heating point, regression analysis.

Rezumat. Astăzi, atât la nivel mondial și european, cât și la cel național, există tendința de promovare a sistemelor centralizate de energie termică în detrimentul celor individuale, pentru încălzirea locuințelor în mediul urban. Luând în considerație actualitatea problemei încălzirii globale și celei legate de epuizarea resurselor energetice primare, cât și a tendinței eficientizării consumului de energie, necesitatea dezvoltării SACET-urilor este incontestabilă. În această lucrare este prezentată metoda aplicării analizei de regresie în studiile de fezabilitate pentru proiectele de conectare a noilor consumatori de căldură la sistemul centralizat de alimentare cu energie termică (în continuare - SACET), sau reconectarea consumatorilor anterior debranșați, prin intermediul punctelor termice individuale (în continuare - PTI), în cazul în care investițiile necesare urmează a fi suportate de operatorul SACET, iar energia termică este produsă în cogenerare. Totodată, este demonstrat faptul că între consumul de combustibil și volumele de energie electrică și termică produse în cogenerare la un CET, există o corelație directă și liniară.

Cuvinte cheie: analiză de regresie, apă caldă menajeră, cogenerare, ecuația liniei drepte, punct termic individual, sezon de încălzire. 


\section{Introduction}

DHS represents a unitary technological and functional ensemble that includes buildings, installations, equipment, specific facilities, and measurement equipment intended for the generation, transmission, distribution, and supply of thermal energy to consumers, respecting efficiency and quality standards [1].

Suppose a DHS is well designed, built, maintained, and constantly developed by implementing the latest and most efficient technologies for production, transmission, and distribution of heat, and consumers pay bills for heating service. In that case, this system can provide quality services at cost small or at least equal to those offered by individual alternative heating solutions and with a much smaller impact on the environment and human health [2].

The most important benefits of district heating, compared to the individual heating systems are less impact on the environment and human health and greater economic efficiency [3 - 4]. The use of DHS compared to individual heating systems allows easier replacement of fossil fuel use with renewable energy sources [5], municipal solid waste, as well as the use of residual heat from other industrial processes [6]. However, the limited comfort of the apartments connected to the DHS, influenced by the way how the system can react to variable loads, represents a disadvantage of using these types of heating systems [7].

To ensure the continuity of quality service providing to consumers, DHS must constantly carry out maintenance and investment measures, with emphasis on the development of solutions, technologies, command and control elements, software packages with higher performance than existing ones, both at the level of production, as well as energy transmission and distribution.

The modernization solution is more advisable than the rehabilitation of an existing DHS. This avoids the risk of maintaining a worn-out system, with modest performance and unprofitable, unable to meet current requirements imposed by the energy market [2].

The modernization/development measures in the DHS can be applied:

1. at the heat source:

- high-efficiency cogeneration production technologies;

- efficient combustion and low pollution boilers;

- $\quad$ pumps with variable speed drives;

- automation, safety, and intelligent monitoring systems;

- heat recovery installations;

- metering of all energy flows, etc.

2. in the transmission and distribution networks:

- $\quad$ pre-insulated pipes with damage signalling system;

- $\quad$ pumps with variable speed drives;

- separation valves with remote electric drive, equipped with measuring and control armature with remote data transmission;

- modern, and high-reliability closing and adjustment armature, etc.

3. at the heating points:

- central heating points conversion to IHP installed in buildings;

- high-efficiency and reliable heat exchangers;

- pumps with variable speed drives;

- metering of all energy flows with remote data transmission, etc.

4. at the consumers' side: 
- IHP installation [8];

- buildings thermal insulation and sealing;

- transition from the vertical heat distribution system to the horizontal distribution system in the internal buildings' heating systems;

- heat and hot water meters installed in each apartment, etc.

In the Republic of Moldova, according to the legal requirements, the investments specified in points 1-3 must be made by the DHS operator and those in point 4 - by the consumer. However, the DHS operator, on the one hand, and the consumers, on the other hand, must represent a partnership, which operates efficiently with common goals and interests.

This article is focused on the economic efficiency evaluation of the modernization projects involving the installation of an IHP.

\section{IHP - a modern solution for the heat consumption streamlining at consumers}

The individual heating point is a set of equipment that provides:

- automatic mode building's heating, with the possibility of the thermal agent temperature automatic adjustment, based on the outdoor air temperature inclusively;

- domestic hot water preparation directly in the building perimeter, thus improving the domestic hot water (DHW) quality.

The IHP installation at the residential block level offers consumers the following advantages:

- heat costs reduction by at least $10 \%$;

- indoor thermal comfort corresponding to the outdoor air temperature, by automatically thermal agent temperature adjustment in the internal heating system depending on the outdoor air temperature;

- $\quad$ preparation of the DHW in building, non-stop at quality parameters;

- $\quad$ safety against explosions and contamination with harmful emissions;

- the possibility to connect/disconnect the building heat supply at the consumer's request;

and to the DHS operator:

- losses reduction associated with the hot water supply;

- DHS image and attractiveness enhancing;

- business stability and more efficient planning.

In the Chisinau DHS, the first IHPs have been installed since the 2003-2004 years. So far, around 900 IHP were installed, which is approx. $21 \%$ of all buildings that is appropriate to equip with IHP. At the same time, it is recommended to connect to the DHS the new consumers or those reconnected after having before disconnected from this system for various reasons via IHP. However, the operator's decision to invest in installing an IHP in a building that is planned to be connected/reconnected to the DHS must be argued by a feasibility study. The study should be based on an economic profitability calculation of the connection project, carried out correctly, taking into account all the necessary investments and the benefits obtained as a result of the sale of an additional amount of thermal energy.

In many DHS, the thermal energy is produced in cogeneration mode. The major motivations for considering cogeneration systems are the potential savings in money and 
energy, and the potential for lower emissions [9]. Therewith, cogeneration is a technique for generating multiple energy products simultaneously in a manner of utilizing high-exergy flows for processes where they are needed and the remaining low-exergy flows where they can be used. Thus an important reduction in irreversibility is achieved in comparison with the separate generation of these products [10].

Of the total thermal energy supplied to consumers connected to Chisinau DHS, about $80 \%$ is produced from cogeneration by the combined heat and power (CHP) plants. In this case, in calculating the economic profitability of connecting a new heat consumer, it is necessary to consider both gains due to additional sales of heat and those related to the sale of electricity produced in cogeneration when assessing revenues.

\section{The regression analysis theory}

The statistical methodology is focused on the regression function to determine the parameters that express to what extent one or more factors influence a variable or process. The estimation of the function parameters that describe the dependence between effect $(y)$ and factors $(x)$ is done by using the regression method. The linear regression method can be successfully applied in the energetics analysis and is used when for a data set represented by pairs of values $\left(x_{i}, y_{i}\right)$, the line that best approximates their placement in the diagram must be found $y=f(x)$.

If the variable or process $y$ is influenced only by one-factor $x$, then simple regression analysis (with a single variable) is applied. For example, it is assumed that there is a linear dependence between two variables, such as the electricity consumed by an enterprise and its production volume. Using the respective data collected over a long time, they can be represented graphically in a diagram of electricity consumption $=f$ (production volume). The points thus obtained are arranged approximately linearly and must determine the line that best approximates the sequence of points, i.e., to find the equation of the form $y=b x+c$, which describes a dependence between discretely represented data. In the considered example, the independent variable $x$ is the production volume during each month of 2020, and the dependent one $y$ is the electricity consumption for each month (Figure 1).

By applying Eq. (1), for any value of the production volume, it is easy to determine the corresponding electricity consumption:

$$
y=46,335 x+56335 \text {. }
$$

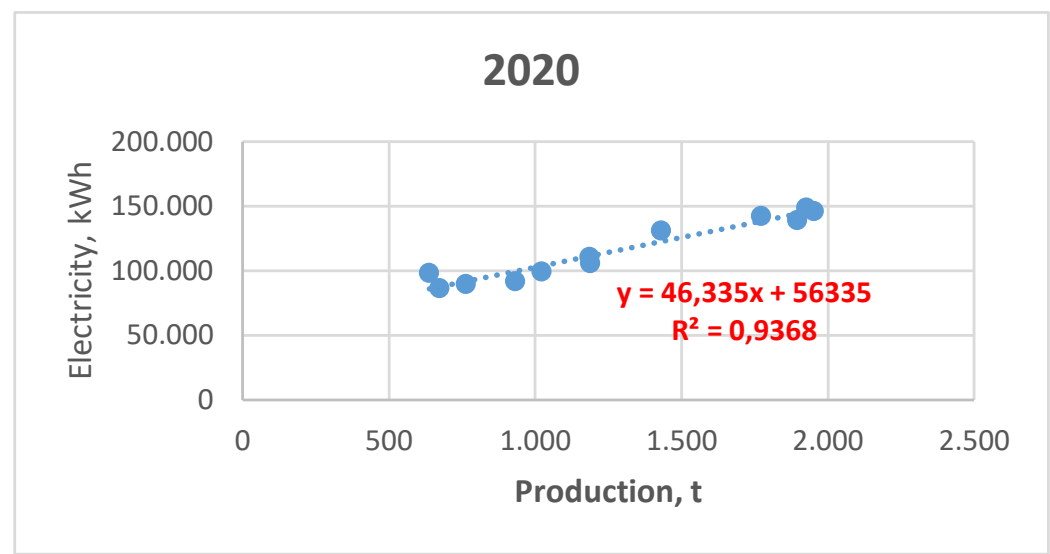

Figure 1. Regression analysis of electricity consumption according to production volume.

The $R^{2}$ value is also significant in determining the dependence intensity of the correlation between the two variable values. The closer to 1 the $\mathrm{R}^{2}$ value is, the more the 
variation of the value $x$ explains the interpretation of the value $y$. The $\mathrm{R}^{2}=0,9368$ (Figure 1) analysis results that in 2020 , the volume of production influenced the enterprise's electricity consumption.

So, the straight-line equation can be used to predict electricity consumption for any variable (driver):

$$
\text { Energy }(y)=\text { Factor } \cdot \operatorname{Driver}(x)+\text { Constant } \text {. }
$$

If the variable or process $y$ is influenced by several factors $x_{1}, x_{2} \ldots x_{n}$, then multiple regression analysis (with two or more variables) is applied.

The linear regression technique must be used with caution, as it can lead to erroneous conclusions. If the data participating in the analysis are lacking, then the conclusions drawn based on an insufficient data set have a low degree of credibility. The more data we have, the higher the degree of trust.

The essence of the linear regression method application to predict the energy produced or consumed depending on certain factors is described in the articles of many researchers. For instance, the article [11] describes the method of multiple regression analysis to predict energy consumption in buildings depending on the outside temperature and the occupancy level of these buildings. The article [12] demonstrates that a country's energy consumption can be predicted by applying the same regression analysis using historical data for the following factors: installed electric capacity of power plants, electricity consumption, heat consumption, population, investments in electric power industry (including district heating, gross domestic product (GDP) and time interval.

\section{The methodology applied for economic efficiency evaluation}

In the following, the methodology for the economic efficiency evaluation of the new consumers' connection to the DHS, or previously disconnected consumers reconnection, by connecting the consumers' internal heating system to the heating networks of DHS, through an individual heating point, when the thermal energy is produced from cogeneration at a combined heat and power (CHP) plant.

One of the primary criteria that can be used to assess the economic efficiency of such a project is the simple payback period - DR, which expresses the number of years during which the initial investment is recovered from the annual income from the project:

$$
D R=\frac{I_{\text {tot }}}{V_{\text {net.an }}}
$$

where $I_{\text {tot }}$ - total project investments; $V_{\text {net.an }}$ - annual net income.

For the project to be considered cost-effective, the simple payback period must be at the level allowed for similar projects and shorter than the lifespan of the project [13]. The lifespan for IHP can be considered as 20 years.

The total investment in the project will be determined with the following formula:

$$
I_{\text {tot }}=I_{H N}+I_{I H P} \text {, }
$$

where: $I_{H N}$ - investment for the heating network acquisition and installation; $I_{\text {IHP }}$ - investment for the IHP acquisition and installation.

The annual net income obtained as a result of the project implementation will be determined with the relation:

$$
V_{\text {net.an }}=V_{\text {brut.an }}-C_{a n} \text {, }
$$

where: $V_{\text {brut.an }}$ - annual gross income; $C_{a n}$ - annual expenses. 
In case of investment in the connection/reconnection projects or installation of an IHP, the DHS operator can obtain income from the increase of additional heat and electricity supply in the network (when heat is supplied from a cogeneration source). In this case, the annual gross income will be determined by the relation:

$$
V_{\text {brut.an }}=Q_{a n} \cdot T_{\text {heat }}+W_{a n} \cdot T_{e l} \text {, }
$$

where: $Q_{a n}$ - the thermal energy quantity supplied to the new consumer; $T_{\text {heat }}$ - the tariff in force for the heat supplied; $W_{a n}$ - the electricity quantity supplied to the network; $T_{e l}$ - the current tariff for the electricity supplied to the network.

The additional annual heat consumption shall be calculated by summing up the heat consumption for the space heating and DHW preparation during and outside of the heating season:

$$
Q_{\text {an }}=Q_{\text {heat.seas. }}+Q_{\text {hot season }}=Q_{\text {heat.seas. }}^{\text {heat }}+Q_{\text {heat.seas. }}^{D H W}+Q_{\text {hot seas. }}^{D H W}
$$

where: $Q_{\text {heat.seas. }}^{\text {heat }}$ - the thermal energy consumption for space heating during the heating season; $Q_{\text {heat.seas. }}^{D H W}$ - the thermal energy consumption for the DHW preparation during the heating season; $Q_{\text {hot seas. }}^{D H W}$ - the thermal energy consumption for the DHW preparation outside of the heating season.

The annual thermal energy consumption supplied to the new consumer for the space heating can be easily determined from the heating load, which depends on the rooms/buildings volume to be heated and the calculation temperatures of indoor and outdoor air [14]. The same, the thermal energy quantity supplied to a new consumer for the DHW preparation can be calculated by knowing the number of the DHW consumers and the specific consumption of DHW, using the methodologies set out in [15-16].

The annual electricity volume - $W_{\text {an }}$ that will be produced additionally with the production of heat for the new consumer during the heating season $-W_{\text {heat.seas. }}$ and also outside of the heating season $-W_{\text {hot seas. }}$ :

$$
W_{\text {an }}=W_{\text {heat.seas. }}+W_{\text {hot seas. }}
$$

can be determined by applying regression analysis, the methodology of which will be presented in the next paragraph.

With the increase of heat and electricity supplies, there will be an increase in fuel consumption at the production source, which is part of the annual expenses, which in turn will be determined by the relation:

$$
C_{a n}=B_{a n} \cdot T_{c o m b}+\text { Amort }_{a n} ;
$$

where: $B_{a n}$ - additional annual fuel consumption; $T_{\text {comb }}$ - the tariff in force for the consumed fuel for the production of heat and electricity; Amort $t_{a n}$ - yearly depreciation of the equipment installed within the project (heat networks and IHP).

The additional annual fuel consumption in case of a new consumer connection will be determined with the relation:

$$
B_{\text {an }}=B_{\text {heat.seas. }}+B_{\text {hot seas. }}
$$

where: $B_{\text {heat.seas. }}$ and $B_{\text {hot seas. }}$ represents the fuel consumption at the production source during the heating season and outside the heating season, respectively.

It should be noted that the correlation between fuel consumption and energy (heat and electricity) produced in cogeneration does not have the same value during a year due to the fact that during the heating season, a higher volume of thermal energy is produced and supplied - for space heating and DHW preparation, while outside of heating season a smaller 
volume of thermal energy is produced only for the DHW preparation. Outside of the heating season, the overall cogeneration efficiency may decrease as thermal load decreases. Respectively, outside of the heating season, the correlation degree between the variables natural gas consumption - heat and electricity supplied, may be lower than during the heating season. This hypothesis can be demonstrated by applying the regression analysis. Also, by using the regression method, the additional volume of natural gas can be estimated in a new consumer connection to the DHS. It is also recommended to determine the extra fuel consumption separately for each season whether the thermal energy is produced at different CHPs depending on the season.

The annual depreciation of the equipment installed in the project can be determined according to the linear depreciation method, using the relation:

$$
\text { Amort }_{\text {an }}=\sum_{i=1}^{n} \frac{V_{i}}{D_{i}} ;
$$

where: $V_{i}$ - the financial value of each mounted equipment; $D_{i}$ - normal service life of the installed equipment; $n$ - number of the installations.

\section{The research methodology}

This article will present the method of applying linear regression in order to predict additional fuel consumption at CHP and the extra volume of electricity produced/supplied to the network in case of the new consumer connection to the DHS or previously disconnected consumer reconnection.

To draw the linear regression model related to the correlation between fuel consumption and additional supplies of heat and electricity produced in cogeneration, in case of new consumer connection to the DHS, as well as to assess the correlation between these two variables, the regression analysis with two variables will be applied (supplied heat and produced electricity), by using the daily data of the heat and electricity produced in cogeneration and supplied to the network, as well as of fuel consumption (natural gas) in a DHS in the Republic of Moldova during 2019.

In the first stage, the hypothesis regarding the correlation between the resultant variables - fuel consumption and the variables considered influencing factors - the supplied heat and the produced electricity separately for the heating season and outside of the heating season should be verified. If high degrees of correlation is established between the variables, in the second stage, the regression models obtained to predict the additional fuel consumption and the additional electricity produced will be applied in case of the new consumer connection to the DHS via IHS.

\section{The regression analysis results: produced electricity - supplied heat}

The corresponding graphs for the heating season and outside of the heating season were constructed to verify the correlation between the additional electricity produced and the heat supplied to the network in case of the new consumer connection to the DHS. Based on the graphs, straight-line equations were generated and established the degrees of influence of the variables on the value $R^{2}$ (Figures 4 and 5). $R^{2}$ must obtain values higher than 0,5 to consider the heat supplied to the network as a determining factor for the produced electricity. 


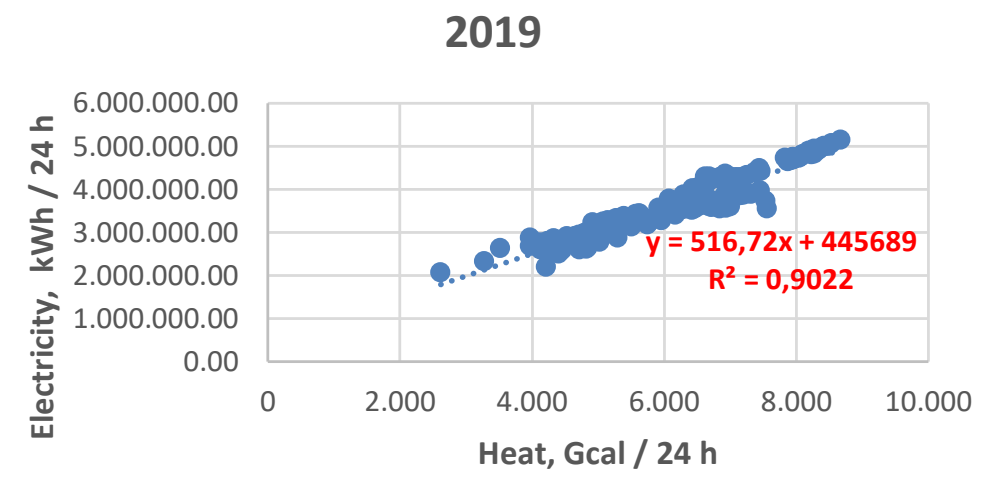

Figure 2. The regression analysis of electricity produced depending on the supplied heat for the heating season.

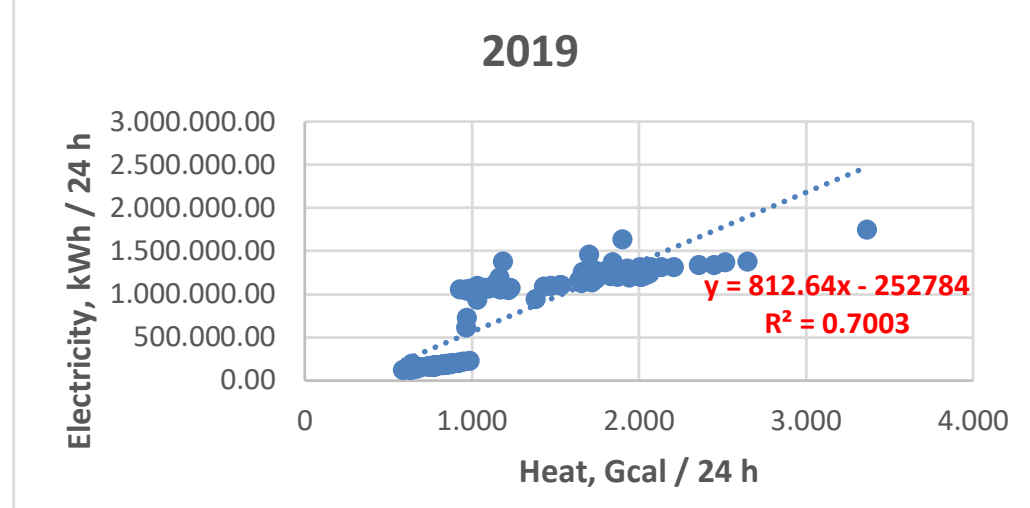

Figure 3. The regression analysis of electricity produced depending on the supplied heat, outside of the heating season.

When analyzing the graphs in Figures 2 and 3, it is observed that the graphical representation of the two variables is a straight line. Thus, it can be stated that there is a direct correlation between the electricity produced and the supplied heat, including the fact that $\mathrm{R}^{2}>0,5$. There is a higher correlation degree during the heating season than outside the heating season, previously assumed in the paper.

\section{The methodology for the calculation of the additional electricity produced}

Thus, for the prediction of the additional electricity produced and supplied to the network, in case of the new consumer connection to the DHS, knowing the volume of thermal energy supplied to this new consumer, a straight-line equation can be used (Figures 2 and 3 ) and methodologies set out in Table 1 (for the heating season, lasting $\tau_{\text {heat.seas }}$ ) and Table 2 (outside of the heating season, lasting $\tau_{\text {hot.seas. }}=365-\tau_{\text {heat.seas. }}$ ).

Table 1

Determination of production indicators at the CHP, during the heating season, as a result of the new consumer connection to the DHS

\begin{tabular}{|c|c|c|c|c|}
\hline \multicolumn{3}{|c|}{$\begin{array}{l}\text { Production indicators until } \\
\text { the connection }\end{array}$} & \multicolumn{2}{|c|}{ Production indicators after connection } \\
\hline $\begin{array}{l}\text { Days of } \\
\text { the season }\end{array}$ & $\begin{array}{l}\text { Supplie } \\
\mathrm{d} \text { heat }\end{array}$ & $\begin{array}{l}\text { Produced } \\
\text { electricity }\end{array}$ & Supplied heat & Produced electricity \\
\hline 1 & $Q_{11}$ & $W_{11}$ & $Q_{12}=Q_{11}+\left(Q_{\text {heat.seas. }}^{\text {heat }}+Q_{\text {heat.seas. }}^{\text {DHW }}+Q_{\text {loss }}\right) / \tau_{\text {heat.seas. }}$ & $W_{12}=516,72 \cdot Q_{12}+445689$ \\
\hline 2 & $Q_{21}$ & $W_{21}$ & $Q_{22}=Q_{21}+\left(Q_{\text {heat.seas. }}^{\text {heat }}+Q_{\text {heat.seas. }}^{D H W}+Q_{\text {loss }}\right) / \tau_{\text {heat.seas. }}$ & $W_{22}=516,72 \cdot Q_{22}+445689$ \\
\hline 3 & $Q_{31}$ & $W_{31}$ & $Q_{32}=Q_{31}+\left(Q_{\text {heat.seas. }}^{\text {heat }}+Q_{\text {heat.seas. }}^{D H W}+Q_{\text {loss }}\right) / \tau_{\text {heat.seas. }}$ & $W_{22}=516,72 \cdot Q_{22}+445689$ \\
\hline
\end{tabular}


Continuation Table 1

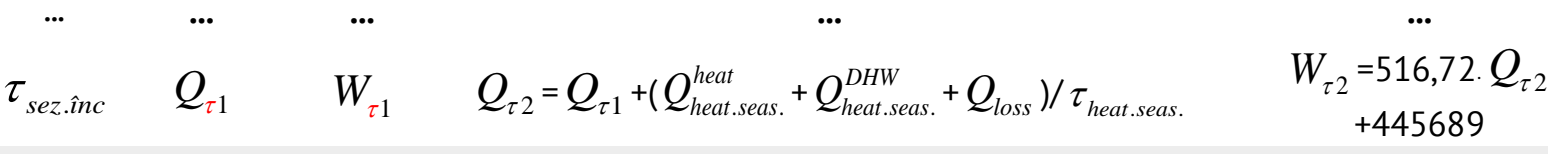

$$
\begin{aligned}
& \text { Total } \sum_{i=1}^{\tau_{\text {heat.s seas. }}} Q_{1} \sum_{i=1}^{\tau_{\text {heat seas. }}} W_{1} \quad \sum_{i=1}^{\tau_{\text {heat. seas }}} Q_{2} \sum_{i=1}^{\tau_{\text {heat.seas. }}} W_{2}
\end{aligned}
$$

Table 2

Determination of production indicators at the CHP, outside of the heating season, as a result of the new consumer connection to the DHS

\begin{tabular}{|c|c|c|c|c|}
\hline \multicolumn{3}{|c|}{$\begin{array}{l}\text { Production indicators until the } \\
\text { connection }\end{array}$} & \multicolumn{2}{|c|}{ Production indicators after connection } \\
\hline $\begin{array}{l}\text { Days of } \\
\text { the } \\
\text { season }\end{array}$ & $\begin{array}{l}\text { Supplied } \\
\text { heat }\end{array}$ & $\begin{array}{l}\text { Days of } \\
\text { the } \\
\text { season }\end{array}$ & Supplied heat & Days of the season \\
\hline 1 & $Q_{11}$ & $W_{11}$ & $Q_{12}=Q_{11}+\left(Q_{\text {hot seas. }}^{\text {DHW }}+Q_{\text {loss }}\right) / \tau_{\text {hot seas }}$ & $W_{12}=812,64 \cdot Q_{12}-252784$ \\
\hline 2 & $Q_{21}$ & $W_{21}$ & $Q_{22}=Q_{21}+\left(Q_{\text {hot seas. }}^{D H W}+Q_{\text {loss }}\right) / \tau_{\text {hot seas. }}$ & $W_{22}=812,64 \cdot Q_{22}-252784$ \\
\hline 3 & $Q_{31}$ & $W_{31}$ & $Q_{32}=Q_{31}+\left(Q_{\text {hot seas. }}^{D H W}+Q_{\text {loss }}\right) / \tau_{\text {hot seas. }}$ & $W_{32}=812,64 \cdot Q_{32}-252784$ \\
\hline$\ldots$ & $\ldots$ & $\ldots$ & $\ldots$ & $\ldots$ \\
\hline$\tau_{\text {sez.cald }}$ & $Q_{\tau 1}$ & $W_{\tau 1}$ & $Q_{\tau 2}=Q_{\tau 1}+\left(Q_{\text {hot seas. }}^{D H W}+Q_{\text {loss }}\right) / \tau_{\text {hot seas. }}$ & $W_{\tau 2}=812,64 \cdot Q_{\tau 2}-252784$ \\
\hline Total & $\sum_{i=1}^{\tau_{\text {hot seas. }}} Q_{1}$ & $\sum_{i=1}^{\tau_{\text {hot seas. }}} W_{1}$ & $\sum_{i=1}^{\tau_{\text {hot seas }}} Q_{2}$ & $\sum_{i=1}^{\tau_{\text {hot seas. }}} W_{2}$ \\
\hline
\end{tabular}

In Table 1, $Q_{\text {loss }}$ represents the distribution heat losses through the new route of the heating networks if the new consumer connection to the DHS requires to build the new thermal networks. Thus, the additional electricity produced and supplied to the network during the heating season, in case of the new consumer connection to the DHS, will be calculated with the relation:

$$
W_{\text {heat.seas. }}=\sum_{i=1}^{\tau_{\text {heat.seas. }}} W_{2}-\sum_{i=1}^{\tau_{\text {heat.seas. }}} W_{1} \text {, }
$$

and the additional electricity produced and supplied to the network outside of the heating season, in case of the new consumer connection to the DHS, will be calculated with the relation:

$$
W_{\text {hot seas. }}=\sum_{i=1}^{\tau_{\text {hot seas. }}} W_{2}-\sum_{i=1}^{\tau_{\text {hot seas. }}} W_{1} .
$$

\section{The regression analysis results: fuel consumption - supplied heat and electricity}

To verify the correlation between fuel consumption and supplied heat and electricity to the network, the regression analysis with two variables will be applied, by applying the Regression feature in the Data Analysis package, from the Microsoft Excel tool. The daily values of fuel consumption are selected as a dependent variable and as independent variables - the thermal energy (variable 1) and electricity (variable 2) supplied to the network separately for the cool and warm seasons. The results generated by the program are shown in Figures 4 and 5 . 
SUMMARY OUTPUT

\begin{tabular}{|c|c|c|c|c|c|}
\hline \multicolumn{2}{|c|}{ Regression Statistics } & & & & \\
\hline Multiple R & 0,99679384 & & & & \\
\hline $\mathrm{R}^{2}$ & 0,99359796 & & & & \\
\hline Adjusted $R^{2}$ & 0,993517431 & & & & \\
\hline Standard Error & 21392,72487 & & & & \\
\hline Observations & 162 & & & & \\
\hline \multicolumn{6}{|l|}{ ANOVA } \\
\hline & $d f$ & SS & MS & $F$ & Significance $F$ \\
\hline Regression & 2 & $1,12933 E+13$ & $5,64666 \mathrm{E}+12$ & 12338,41704 & $4,0023 E-175$ \\
\hline Residual & 159 & 72766139714 & 457648677,4 & & \\
\hline Total & 161 & $1,13661 \mathrm{E}+13$ & & & \\
\hline
\end{tabular}

\begin{tabular}{lcrrrrrrr}
\hline & Coefficients & \multicolumn{1}{c}{ Standard Error } & \multicolumn{1}{c}{ t Stat } & \multicolumn{1}{l}{ P-value } & \multicolumn{1}{c}{ Lower 95\% } & \multicolumn{1}{c}{ Upper 95\% } & \multicolumn{1}{l}{ Lower 95,0\% } & Upper 95,0\% \\
\hline Intercept & $\mathbf{5 0 1 9 3 , 7 0 7 3 2}$ & 9094,890582 & 5,51889073 & 0,0000001 & 32231,33287 & 68156,08178 & 32231,33287 & 68156,08178 \\
X Variable 1 & $\mathbf{8 9 , 8 8 9 0 4 0 2 4}$ & 4,219549583 & 21,30299419 & 0,0000000 & 81,5554458 & 98,22263469 & 81,5554458 & 98,22263469 \\
X Variable 2 & $\mathbf{0 , 2 2 0 6 5 6 8 5 6}$ & 0,007756297 & 28,44873691 & 0,0000000 & 0,205338199 & 0,235975514 & 0,205338199 & 0,235975514 \\
\hline
\end{tabular}

Figure 4. The results of the data processing: fuel consumption - energy supplied to the network during the cool season, by the linear regression method.

SUMMARY OUTPUT

\begin{tabular}{lr}
\hline \multicolumn{2}{c}{ Regression Statistics } \\
\hline Multiple R & $\mathbf{0 , 9 9 1 2 3 8 6 8 1}$ \\
$\mathrm{R}^{2}$ & 0,982554122 \\
Adjusted R & 0,982326071 \\
Standard Error & 24297,3477 \\
Observations & 156 \\
\hline
\end{tabular}

ANOVA

\begin{tabular}{lrrrrr}
\hline & $d f$ & \multicolumn{1}{c}{ SS } & \multicolumn{1}{c}{ MS } & \multicolumn{1}{c}{$F$} & Significance $F$ \\
\hline Regression & 2 & $5,08713 \mathrm{E}+12$ & $2,54356 \mathrm{E}+12$ & 4308,489946 & $3,0868 \mathrm{E}-135$ \\
Residual & 153 & 90325249130 & 590361105,4 & & \\
Total & 155 & $5,17746 \mathrm{E}+12$ & & & \\
\hline
\end{tabular}

\begin{tabular}{lcrrrrrrr}
\hline & Coefficients & Standard Error & \multicolumn{1}{c}{$t$ Stat } & \multicolumn{1}{c}{ P-value } & \multicolumn{1}{c}{ Lower 95\% } & \multicolumn{1}{c}{ Upper 95\% } & \multicolumn{1}{l}{ Lower 95,0\% } & Upper 95,0\% \\
\hline Intercept & $\mathbf{3 7 4 0 6 , 3 9 8 2 1}$ & 5144,886607 & 7,27059721 & $1,72472 \mathrm{E}-11$ & 27242,21006 & 47570,58636 & 27242,21006 & 47570,58636 \\
X Variable 1 & $\mathbf{4 3 , 1 7 7 1 9 4 2 2}$ & $\mathbf{6 , 7 5 1 3 1 7 0 1 9}$ & $\mathbf{6 , 3 9 5 3 7 3 5 4}$ & $1,84477 \mathrm{E}-09$ & 29,8393577 & 56,51503074 & 29,8393577 & 56,51503074 \\
X Variable 2 & $\mathbf{0 , 3 1 5 2 4 5 2 7 3}$ & 0,006952531 & 45,34252273 & $1,32746 \mathrm{E}-90$ & 0,301509921 & 0,328980625 & 0,301509921 & 0,328980625 \\
\hline
\end{tabular}

Figure 5. The results of the data processing: fuel consumption - energy supplied to the network during the warm season, by the linear regression method.

Analyzing the high values of the multiple correlation coefficients $R=0,996$ for the cool season and $R=0,991$ for the warm season, it results that there is a high intensity of the correlation between fuel consumption and all independent variables - heat and electricity supplied to the network during the 2019 year. The same is demonstrated by values greater than 0,05 obtained for Significance $F$ and $P$-Value.

\section{The methodology for the calculation of the additional fuel consumption at the CHP}

For the prediction of additional fuel consumption at the CHP, in case of the new consumer connection to the DHS, knowing the additional volumes of the heat and electricity supplied to the network, the coefficients obtained as a result of the regression analysis (Figures 4 and 5) and the methodologies set out in Table 3 (for the heating season, lasting $\tau_{\text {heat.seas.) }}$ ) and Table 4 (outside of the season, lasting $\tau_{\text {hot seas. }}=365-\tau_{\text {heat.seas. }}$ ). 
Table 3

The fuel consumption determination at CHP, during the heating season, as a result of a new consumer connection to the DHS

\begin{tabular}{|c|c|c|c|}
\hline \multicolumn{4}{|c|}{ Production indicators after connection } \\
\hline $\begin{array}{l}\text { Days of } \\
\text { the } \\
\text { season }\end{array}$ & Heat supplied & Electricity produced & Natural gas consumption \\
\hline 1 & $Q_{12}$ & $W_{12}$ & $B_{12}=50193,707+89,889 \cdot Q_{12}+0,220 \cdot W_{12}$ \\
\hline 2 & $Q_{22}$ & $W_{22}$ & $B_{22}=50193,707+89,889 \cdot Q_{22}+0,220 \cdot W_{22}$ \\
\hline 3 & $Q_{32}$ & $W_{32}$ & $B_{32}=50193,707+89,889 \cdot Q_{32}+0,220 \cdot W_{32}$ \\
\hline$\ldots$ & $\ldots$ & $\ldots$ & $\ldots$ \\
\hline$\tau_{\text {sez.inc }}$ & $Q_{\tau 2}$ & $W_{\tau 2}$ & $B_{\tau 2}=50193,707+89,889 \cdot Q_{\tau 2}+0,220 \cdot W_{\tau 2}$ \\
\hline Total & $\sum_{i=1}^{\tau_{\text {heat seas. }}} Q_{2}$ & $\sum_{i=1}^{\tau_{\text {heat. seas. }}} W_{2}$ & $\sum_{i=1}^{\tau_{\text {heat. seas. }}} B_{2}$ \\
\hline
\end{tabular}

Thus, the additional fuel consumption at the heat source during the heating season, in case of a new consumer connection to the DHS, will be calculated with the relation:

$$
B_{\text {heat.seas. }}=\sum_{i=1}^{\tau_{\text {heat.seas. }}} B_{2}-\sum_{i=1}^{\tau_{\text {heat.seas. }}} B_{1} \text {, }
$$

where: $\sum_{i=1}^{\tau_{\text {heat. sas. }}} B_{1}$ - fuel consumption at CHP during the 2020 heating season, before the connection of the new consumer.

Table 4

Determination of the fuel consumption at CHP, outside of the heating season, as a result of a new consumer connection to the DHS

\begin{tabular}{|c|c|c|c|}
\hline \multicolumn{4}{|c|}{ Production indicators after connection } \\
\hline $\begin{array}{c}\text { Days of the } \\
\text { season }\end{array}$ & $\begin{array}{c}\text { Heat } \\
\text { supplied }\end{array}$ & Electricity produced & Natural gas consumption \\
\hline 1 & $Q_{12}$ & $W_{12}$ & $B_{12}=37406,398+43,177 \cdot Q_{12}+0,315 \cdot W_{12}$ \\
\hline 2 & $Q_{22}$ & $W_{22}$ & $B_{22}=37406,398+43,177 \cdot Q_{22}+0,315 \cdot W_{22}$ \\
\hline 3 & $Q_{32}$ & $W_{32}$ & $B_{32}=37406,398+43,177 \cdot Q_{32}+0,315 \cdot W_{32}$ \\
\hline ... & $\ldots$ & $\ldots$ & $\ldots$ \\
\hline$\tau_{\text {sez.cald }}$ & $Q_{\tau 2}$ & $W_{\tau 2}$ & $B_{\tau 2}=37406,398+43,177 \cdot Q_{\tau 2}+0,315 \cdot W_{\tau 2}$ \\
\hline Total & $\sum_{i=1}^{\tau_{\text {hot seas. }}} Q_{2}$ & $\sum_{i=1}^{\tau_{\text {hot seas. }}} W_{2}$ & $\sum_{i=1}^{\tau_{\text {hot seas. }}} B_{2}$ \\
\hline
\end{tabular}

Thus, the additional fuel consumption at CHP outside of the heating season, in case of a new consumer connection to the DHS, will be calculated with the relation:

$$
B_{\text {hot seas. }}=\sum_{i=1}^{\tau_{\text {hot ses. }}} B_{2}-\sum_{i=1}^{\tau_{\text {hot seas. }}} B_{1}
$$

where: $\sum_{i=1}^{\tau_{\text {hot seas. }}} B_{1}$ - fuel consumption at CHP during the 2019 warm season, before the connection of the new consumer. 


\section{Conclusions}

The regression analysis use, having as variables the thermal energy supplied to the DHS and the additional electricity produced in cogeneration at CHP, demonstrated a direct and linear correlation between these two variables. The same was shown for the correlation between fuel consumption and the electricity and heat produced in cogeneration at CHP.

Thus, it is recommended to use the regression analysis methods described in the article to predict the additional electricity produced, along with the heat supplied to the new heat consumer connected to any DHS in which these two forms of energy are produced simultaneously, as well as to predict additional fuel consumption in this case.

The obtained results can be used in the feasibility studies for projects of new consumers connection to the DHS via IHP by applying the method of economic evaluation of these types of projects presented in the article.

\section{References}

1. Antocel D. Modernization solutions for the centralized heat supply systems of the mun. Chisinau. In: Engineering Meridian, 2009, nr.1, pp.20-29.

2. Parsian G. Public service of centralized district heat supply and tariff setting up principles. In: Engineering Meridian, 2009, nr.1, pp.15-19.

3. Tirsu M., Lupu M., Postoronca Sv. Impact of centralized and individual heating systems in residential buildings from Environmental Considerations. Case study for Chisinau. In: Problems of the regional energetics, 2019, nr.2(43), pp.48-63.

4. Lisnic V., Arion V. Economic comparison of options - individual heating or central heating. In: TechnicalScientific Conference of Collaborators, PhD Students and Students TUM, 2017, Volume 1, pp.401-404.

5. Hakan I. District Heating in Areas with Low Energy Houses: Ph.D. Thesis. Denmark: Technical University of Denmark, 2015.

6. Domingo A.M, Hernandez J.R., Alonso J.J., Crespo R.M., Martinez J.R. Energy efficiency analysis carried out by installing district heating on a University Campus. A case study in Spain. In: Energies, 2018, Volume 11(10).

7. Bianchi A., Marinescu M., Hera D., Dimitriu S., Ivan G., lonescu M., Băltărețu FL. District heating system in Romania; Development directions [online]. [accesed 06.09.2021]. Available: http://aspeckt.unitbv.ro/jspui/bitstream/123456789/1240/1/Bianchi.pdf

8. Cernei M., Leu V. General problems of Moldova District Heating Systems. In: Problems of the regional energetics, 2016, nr.1(30), pp.84-88.

9. Caton J.A. Cogeneration. In: Myer, K., ed Environmentally Conscious Alternative Energy Production. New Jersey: John Wiley \& Sons, 2007, pp.129-164.

10. Ljubenko A., Poreodos A., Morosuk T., Tsatsaronis G. Performance Analysis of a District Heating System [online]. [accesed 17.05.2021]. Available: https://www.researchgate.net/publication/274443594_Performance_Analysis_of_a_District_Heating_System

11. Safa M., Allen J., Safa M. Predicting energy usage using historical data and linear models. In: The 31 ${ }^{\text {st }}$ International Symposium on Automation and Robotics in Construction and Mining (ISARC 2014), 2014, pp.531-535.

12. Dobrovolskaia T., Stennikov V. Regression model for heat consumption monitoring and forecasting. In: E3S Web Conference Mathematical Models and Methods of the Analysis and Optimal Synthesis of the Developing Pipeline and Hydraulic Systems, Volume 39, 2018.

13. AEE. Ghid privind evaluarea economică a proiectelor din domeniile eficienței energetice și energiilor regenerabile [Guide on the economic evaluation of projects in the fields of energy efficiency and renewable energies]. Chisinau: Sirius, 2014.

14. Chelmenciuc C., Butenco N., Baboi N. Sisteme de încălzire cu apă și aer cald [Water and hot air heating systems]. Chisinau: UTM, 2012.

15. Practical code in constructions CP G.04.13:2016 Design of heat points. Chisinau: ICȘC INCERCOM, 2016.

16. Normative in constructions NCM G.03.03:2015 Interior installation of water and sewage. Chisinau: ICSC INCERCOM, 2015. 